\title{
Organizational and Institutional Crisis Management
}

Sanneke Kuipers, Institute of Security and Global Affairs, Leiden University

and Jeroen Wolbers, Institute for Security and Global Affairs, Leiden University

https://doi.org/10.1093/acrefore/9780190228637.013.1611

Published online: 25 March 2021

\section{Summary}

Research on organizational crisis emanates from multiple disciplines (public administration, international relations, political science, organization science, communication studies), yet basically argues that three main categories of crises exist:

- Crises in organizations: often tangible, immediate threats or incidents that completely upset an organization's primary process or performance, while both cause and problems are more or less confined to the organization and those affected by its malperformance.

- Crisis to the organization: a threat or damage occurs outside of the organization at hand but implicates the organization by attribution of responsibility or culpability (for causing the problems or allowing them to occur).

- Crisis about the organization, or institutional crisis: even without a tangible threat or damage, in a short period of time the organization's perceived performance deficit becomes so deeply problematic that the organization itself is subject to intense scrutiny and criticism. Previously agreed-on values and routines, the structure, and policy philosophy of the organization are no longer seen as adequate or legitimate.

The three types of organizational crises tend to have not only different causes but also different implications as to the commensurate crisis response, both functionally and politically. There is no single best response to organizational crises: appropriate responses are both commensurate to the crisis type at hand and to different phases of a crisis. Still, discerning between crisis typologies opens a research agenda to provide a better understanding of the relation between the internal and external dynamics of a crisis.

Keywords: organizational crisis, institutional crisis, typology, crisis management, politics, legitimacy, sensemaking, crisis analysis

\section{Three Types of Organizational Crises}

When an organization experiences a crisis, it faces a highly ambiguous situation in which cause and effect are unknown; the viability of the organization is threatened; and little time is available to respond (Pearson \& Clair, 1998). Generally, crisis management teams are equipped to respond to a crisis in their environment, but in some cases the crisis affects the 
organization itself, questioning its capacity and legitimacy. This is known as an institutional crisis (Boin, Kuipers, et. al., 2017). Numerous studies have provided insights on how such a profound decline in legitimacy affects public institutions and even entire policy sectors, and how public institutions deal with such as crisis (Alink et al., 2001; Ansell et al., 2016; Boin \& 't Hart, 2003; Leijtens, 2019; Nohrstedt et al., 2018; Schmidt et al., 2018; Useem et al., 2017).

Perhaps the best-known example of institutional crisis can be found in the Tennessee Valley Authority (TVA). The TVA, a jewel in the crown of Roosevelt's New Deal, was established in 1933 as a corporation empowered with government authority and yet characterized by the flexibility and initiative of a private enterprise (Hargrove, 1994). The TVA's mission was to enhance and protect the Tennessee Valley Region by fighting soil erosion, controlling the river, and exploiting hydroelectric power all at the same time. Meanwhile, it would provide work in times of economic depression and raise the national standards for the provision of electricity (Kuipers \& Boin, 2010). It did so successfully, for decades, while the TVA moved from hydroelectricity to exploiting coal plants, and then later providing nuclear energy. Its organizational mission to enhance and protect the Valley, with electricity as a byproduct, got lost in the process. Fifty years later, it seemed as if the TVA had spiraled out of control-in 1985, the Nuclear Regulatory Commission forced the TVA to close down five of its reactors for safety reasons while the construction of other reactors was stalled or canceled. The costs of their nuclear program had risen uncontrollably and illegitimately, at the expense of public safety and taxpayers' money. As a consequence, the TVA was exposed to intense public and congressional scrutiny and criticism. Two chairmen of its executive board had to step down; almost half of the staff was laid off; and the TVA became subject to a drastic reorganization (Kuipers \& Boin, 2010, p. 54; cf. Hargrove, 1994). The institutional crisis was complete.

Conceptual and empirical insights on institutional crises have enriched and complemented our studies on organizational crises, which traditionally focus on more tangible problems and incidents-"negative surprises"-within organizations (Lagadec, 1993; Pauchant \& Mittroff, 1992; Pearson \& Clair, 1998). Despite this focus on crises that occur within the organization itself, there are a range of crises that affect an organization in more indirect ways. This article contributes to the literature on organizational crises by discerning more clearly between:

- Crises in organizations: often tangible, immediate threats or incidents that completely upset an organization's primary process or performance, while both cause and problems are more or less confined to the organization and those affected by its malperformance.

- Crisis to the organization: a threat or damage occurs outside of the organization at hand but implicates the organization by attribution of responsibility or culpability (for causing the problems or allowing them to occur).

- Crisis about the organization: even without a tangible threat or damage, in a short period of time the organization's perceived performance deficit becomes so deeply problematic that the organization itself is subject to intense scrutiny and criticism. Previously agreedon values and routines, the structure, and policy philosophy of the organization are no longer seen as adequate or legitimate.

Each of the three crisis types can be devastating to an organization and threaten its future existence. The distinction is valuable because different scholarly contributions study different crisis types and discern both functional and more political approaches to crisis management. The type of crisis they study is often treated as a given rather than a variable (cf. Kalbassi \& 
Kauf, 2017; Kuipers, 2019). Yet, little systematic overview exists on what approaches are used for what crisis type and in what way. Even the most tangible crises in organizations do not only prompt a functional response (putting out the fire, informing those directly affected), but have a political dimension too (regarding the legitimacy of the organization, and accountability for the problems and its functional response to the crisis). In line with Kenis et al. (2019), it is important to adopt a contingency perspective to organizational crises. This means that there is no single best response to all organizational crises: appropriate responses are commensurate to the crisis type at hand as well as to different phases of a crisis.

\section{Defining Organizational Crises}

Departing from a classic crisis definition that includes elements such as threat, uncertainty, and urgency (Rosenthal et al., 1989), organizational crises are all those threats or negative incidents that require an urgent response by the organization under conditions of considerable uncertainty as to the precise causes and probable consequences of the situation at hand. For the study of organizational crises, it is important to first define the crisis in terms of both level of perception and characteristics of the situation. First, the level of perception matters: to whom is this a crisis, and how does the crisis affect the organization? In organizations and professions, a crisis means something different to a banker than to a childcare worker, a politician, or a cardiologist. And yet there are insightful patterns and common challenges to managing crisis situations in a wide variety of organizations from different professional domains.

Second, looking at the traits of the threat or crisis situation, insights on crisis management also come from many different domains. Studies on politics and international relations see crises as unanticipated threats to high-priority values of the organization, which allow for a restricted response time (Hermann, 1963). Disaster studies would add that crises are also disruptive, as they upset routines, infrastructures, networks, and communication lines (Quarantelli \& Dynes, 1977). In public affairs and business administration, emphasis is placed on the unexpected nature of crises and that they damage reputation and stakeholder satisfaction (Coombs \& Holladay, 2002).

Over time, most organizational crises involve all of the previous traits to some extent. First of all, the element of "threat" points at the fact that a sudden, major risk can also require crisis management to prevent its negative or even disastrous consequences. What constitutes a threat is in the eye of the beholder; when crucial stakeholders define a situation as a crisis, it is a crisis in its consequences (Boin et al., 2017, p. 20). Second, crisis situations usually require an urgent response, a form of "crisis management," because the window to mitigate the damage is strictly time-bound. These crises differ in that respect from other grave dangers or societal threats such as climate change or microbial resistance (Boin et al., 2020). The idea that it is possible to intervene and curb the threat sets the crisis approach apart from classic disaster studies (Boin, Kuipers, et al., 2017). Uncertainty is the third defining element. The fact that most crises come as a surprise-that is, are unexpected-means that those who face the crisis first need to grasp exactly what is going on. Negative consequences or worrying symptoms indicate that something is amiss. But what? What caused it? Where? How? The spill 
is sometimes easier to detect than the leak. A breakdown is much more visible than the vulnerability or pressure that caused it and that continues to be a threat. Solutions are seldom clear (Boin, Kuipers, et al., 2017).

Once a crisis has escalated, the organization needs to fight both the causes and the disruptive consequences, meanwhile scrambling for answers on the most basic questions such as what, where, and how. The disruptive nature of most crises can at the same time mean that the capacity to solve it is either overwhelmed or paralyzed. Think of an ICT breakdown and its effect on core services or production processes, internal communication lines, and the ability to retrieve vital information-effects that occur all simultaneously.

The twin fight against causes and consequences is not only an internal affair to organizations. Crises destroy reputations and stakeholder trust in an instant. This brings us back to discussing the nature of the threat. The assessment of how the crisis relates to the core values and the mission of the organization is crucial. Coombs and Holladay (2002) point out that the organization's prior relation to its environment defines its room to maneuver in crisis management. When responding to a crisis, organizational leaders need to prioritize and first define what is at stake. What values does the organization embody, and what are its crown jewels? Is it watertight information security? Or excellent service delivery? Or top-notch technical reliability? Or social equality and access for all? Related, what threat does the crisis pose? What should be the commensurate response given our reputation and our stakeholders?

Overall, an organizational crisis requires a swift but balanced response on multiple levels. It starts with developing an adequate perception of the crisis, moves toward identifying the cause and its disruptive consequences, and eventually results in managing the accountability process and the organization's reputation. This article focuses on organizational crises from a diversity of research strands to both public and private organizations by probing into both the internal and the external dimension of crisis management, drawing on insights from the studies on the politics of crisis management, from disaster and emergency response, and from public affairs. It allows a discussion of crises both as physical threats and damage and as sudden declines of trust and legitimacy.

In this article, state-of-the-art insights on the causes, management, and consequences of varying organizational crises are reviewed. In "Causes: From Organizations in Crisis to Institutional Crisis," types of organizational crisis are discussed and their causes identified. "Organizational Crisis Management" provides state-of-the-art insights on the main challenges and coping strategies for organizational crisis in terms of functional and political responses, and reviews the consequences: the organizational crisis and in particular the institutional crisis type can impact political agenda setting and open windows for reform or new regulation. "Conclusion and the Road Ahead" offers a synopsis of current academic literature, where the gaps appear in current studies and what avenues are required further research. 


\section{Causes: From Organizations in Crisis to Institutional Crisis}

\section{Human Error and System Complexity Causing Crisis in the Organization}

Classic case examples of organizations in crisis are those that (a) start with a "bang" or negative surprise; (b) lead to tangible loss of life, property, or well-being in the organization and its immediate environment; and (c) usually have the name of the organization involved stuck to it. Think of the BP oil spill, the Mariott data breach, the crashes of several Boeing 737 Max aircraft since it entered service in 2016, the Rana Plaza collapse, and the Chernobyl nuclear disaster. An incident either drives the organization out of business right away or disrupts its core processes to such an extent that it poses a major threat for the organization's future.

Organization scholars have long been interested in crises and crisis management, but they view it from a particular set of perspectives including strategic management, organizational theory, and organizational behavior research, as well as research in public relations and corporate communication (Bundy et al., 2017, p. 1661). Though several authors lament the siloed approach to studying crises, the gap between different research traditions, particularly along the lines of business administration, on the one hand, and public administration, on the other, persists (Bundy et al., 2017; James et al., 2011; Kahn et al., 2013). The public administration scholars, focusing on both the operation and collaboration of emergency services as well as the "politics of crisis management" at a more strategic level, do capitalize on findings from the organization studies literature (Ansell \& Boin, 2019; Boin, Kuipers, et al., 2017; Rosenthal et al., 1989; Stern \& Sundelius, 2002) but draw mainly on public administration, political science, political psychology, disaster sociology, and international relations. Their findings do not seem to feed into the business administration debates.

The studies on crises in organizations heavily focus on the causes of crises and on the dynamics of managing risk, complexity, and technology within organizations (Bundy et al., 2017, referring to Bigley \& Roberts, 2001; Gephart et al., 2009; Pearson \& Clair, 1998; Starbuck \& Milliken, 1988). They stand on the shoulders of giants such as Barry Turner for his work on organizational failure of foresight and Charles Perrow for his work on normal accidents, which emphasize the inevitability of human-made disasters, either due to the complexity of the systems they work with (Perrow, 1984) or to the accumulation of deficiencies in human interaction (Turner, 1978). As a rebound, the so-called "Berkeley school" argued that crises are by no means inevitable, as evidenced by high-reliability organizations that exhibit an exceptional performance while operating high-risk, highly complex systems in a failure-intolerant environment, such as aircraft carriers and nuclear plants (La Porte, 1996; Roberts, 1990; Roe \& Schulman, 2008; Weick \& Sutcliffe, 2001). These types of high-reliability organizations focus on the prevention of disastrous system breakdowns through changes in culture, design, and structure of their organization (Bundy et al., 2017). When crises do occur in organizations, the causes, according to the above literatures, can likely be found in the interactive complexity and tight coupling of high-risk technology, and in the organizational and individual human failure to deal with these risks. Latent failures, as James Reason and Barry Turner call them, as well as accumulating deficiencies within organizations, allow small errors to trigger escalation processes that may lead to disastrous consequences (Reason, 2000; Turner, 1976). 
Organizational routines and procedures should be in place to prevent human action from inadvertently triggering such failure and to stop the escalation process when human errors are made. Five basic principles of high-reliability theory-preoccupation with failure; reluctance to simplify; sensitivity to operations; commitment to resilience; and deference to expertise-help to institutionalize safety and operational reliability in high-risk organizations (Weick \& Sutcliffe, 2001). These theoretical contributions do not just deal with preventing the technical causes or initial triggers; instead, they also emphasize the importance of avoiding "intelligence failures" that Turner lists as the real causes of escalation from initial trigger to full-blown disaster (Turner, 1976). The underestimation of emerging dangers, ignoring outside complaints or criticism, or assuming that other organizations or actors responsible for a particular aspect of safety have the same information are examples of intelligence failures with devastating consequences when several factors come into play simultaneously once a risk or threat manifests.

Indeed, a crucial first phase of getting in front of a crisis is to recognize the degree of emerging risk and acquire the ability to act on that information (Comfort, 2007). If important signals are missed in the phase leading up to the trigger event of a crisis (Turner, 1976), crisis managers may be blamed after the crisis for not having acted on those signals. Initial recognition can be quite difficult, as in the first turbulent phase of a crisis the internal system of beliefs, norms, and values is under scrutiny. In order to make sense of a deviant event, crisis managers need to have a clear concept of how the setting they are going to operate in should work (Weick, 1995). People commit to a frame because it renders sequences of events meaningful by helping individuals to classify and predict the behavior of others, which helps them from the very first signal that something's amiss; and to coordinate action and make critical decisions (Cornelissen et al., 2014). Although commitment to a frame is crucial for managing expectations, it might also entrap individuals and hinder their ability to perceive changes in their environment. Studies of crisis sense-making have shown that a firm commitment to a frame can create substantial blind spots that impede adaptation (Maitlis \& Sonenshein, 2010).

A classic example of a failure to make sense of emerging risk occurred during one of the largest industrial disasters, at Union Carbide's methyl isocyanate plant in Bhopal (Weick, 2010). The disaster was triggered during maintenance work when, during a pipe flushing operation, water accidentally washed back into a tank with methyl isocyanate, building up heat and pressure that eventually resulted in an explosion and a major gas leak. The plant managers had assumed that nothing could go wrong, as the factory had been shut down for six weeks. At the same time, the situation in the factory was deplorable, with control boards not working, broken gauges, corroded lines, and malfunctioning valves (Weick, 1988). The poor condition of the plant meant that cues signaling that something was wrong were hard to interpret. Plant managers neglected signals provided by their operators signaling the danger of failure, including the odor of gas. This neglect corresponds with a range of studies that reconstruct the origins of a collapse of sense-making; their claim is that departing from a false frame of the situation is extremely difficult, as new cues are likely to be interpreted and justified into the existing frame (Cornelissen et al., 2014; Weick, 1993).

In sum, a crisis in the organization is often triggered by a combination of human error and system complexity. A crisis disrupting the core processes of an organization may pose a major threat to that organization. It often is difficult for professionals within an organization to make sense of crises that strike them, as dominant frames and ways of working often contribute to 
the causes of the crisis. Although this type of crisis is one of the most visible forms in the literature, organizations might also be implicated in a crisis that occurs outside of their boundaries.

\section{Crisis to the Organization: Responsibility and Culpability by Attribution and Implication}

The second form of organizational crisis is the crisis to the organization. This type of crisis occurs when very tangible threats or risks materialize into full-blown disasters that affect (other) organizations by implication. The range of examples from different sectors includes natural hazards, terrorism, or industrial production. For instance, the catastrophic disaster of Hurricane Katrina exposed institutional deficiencies in the U.S. disaster response system that had focused too much on homeland security and too little on disaster management (Kettl, 2003). The terrorist attack of 9/11 on the Twin Towers and the Pentagon exposed the inability of the U.S. intelligence community to cooperate in order to exchange and interpret preexisting signals adequately (Zegart, 2009).

In these cases, organizations did not recognize a crisis in the making, and their failure to prevent came back to haunt them. They failed to foresee a crisis because they had developed blind spots and rigid beliefs about their task environment that prevented them from taking adequate precautions. In that sense, crises and disasters expose "a collapse of precautions that had hitherto been regarded culturally as adequate" (Turner, 1976, p. 380). Turner aptly points out that this definition pertains to patterns preceding disaster in his study but also can be found as precursors of less life-threatening extreme events, such as "the collapse of a major public company" (p. 380). The triggering event sparks off a conflict over pre-existing assumptions, expectations, and agreements regarding the legitimate performance or existence of a particular government arrangement or a particular public organization (see also Laufer \& Wang, 2018, on crisis contagion).

The role rigid beliefs and blind spots play in failure to recognize the importance of an ongoing crisis is clearly visible in the case of the World Health Organization's response to Ebola. In December 2013, in a remote forested Guinean village close to the borders of Sierra Leone and Liberia, the first cases appeared of what retrospectively turned out to be the "largest and most complex outbreak of Ebola ever" (Baize et al., 2014, p. 1418). It would take the WHO more than 3 months to first publicly acknowledge the disease outbreak, when already 111 clinically suspected cases and 79 casualties had been identified (Honigsbaum, 2017, p. 271). The WHO further waited until August to declare the Ebola outbreak a public health emergency of international concern, finally giving in to international pressure. In the meantime, the outbreak in West Africa had, in the words of Medicins Sans Frontieres (MSF), spiraled "totally out of control" (p. 272). Honigsbaum (2017) argues that the WHO, the international organization responsible for global disease prevention and providing aid to governments in emergencies, long held on to the paradigm that Ebola had over the decades become a self-limiting tropical disease that could be contained with relatively low-tech interventions (cf. Lakoff, 2015). WHO was misled by ambiguous data from local authorities who minimized the magnitude of the outbreak in their reports out of fear for economic consequences (p. 287). In the aftermath of the crisis, the WHO was severely criticized for initially relegating Ebola to the fringes of global health security instead of recognizing and 
responding in a timely manner to its significant risk of international spread with potentially disastrous consequences (p. 293). As such, the Ebola crisis exposed the organizational failure of the WHO (Coltart et al., 2017).

The scale of the Ebola outbreak and its severity were underestimated and minimized by authorities and experts at all levels, but the WHO was particularly singled out for criticism (Coltart et al., 2017; cf. McInnes, 2015). Subsequent academic studies would reveal that its administrative system for risk triage did not trigger robust action to Ebola because the disease was not classified as an alarming "hot virus" because of experiences in the previous decades with responding to and containing the virus (Honigsbaum, 2017). Also, the budget of the global health guardians did not exactly meet their ambitions: the WHO budget "stagnates at a meager US $\$ 2$ billion," compared to the U.S. Centers for Disease Control and Prevention's access to US\$6.9 billion annually (Kekulé, 2015, p. 3797). For the SARS outbreak in 2003, which had affected mainly affluent countries, the division of responsibility for epidemic disease control between WHO and member states had been appropriate for the response required. By contrast, for containment of infectious diseases in developing countries, WHO had neither the resources nor the policy in place (Kamradt-Scott, 2016, p. 401). The WHO did not have the technical support capacity that it seriously needed to respond effectively to Ebola in West Africa, nor could it rely on its model of delegated expertise and authority (Coltart et al., 2017; Kekule, 2015; McInnes, 2015).

Another case of crisis to an organization are the earthquakes in the northern part of the Netherlands that were triggered by the extraction of natural gas. The gas production company Nederlandse Aardolie Maatschappij (NAM, a Shell and ExxonMobil consortium) involved in the production of natural gas from the underground mineral source in the North of the Netherlands, failed to recognize the growing public discontent about the risk of repeated earthquakes caused by gas production. After the occurrence of the first earthquake in 1986, the NAM persistently responded by employing a technical frame to investigate the exact nature of the earthquakes, the causal relation between earthquakes and gas production, and the assessment of acceptable risk. Although the frequency and magnitude of earthquakes had been gradually increasing over the years, the experts continued to interpret the risk as a highly technical matter that required more incidents and measurement before it could lead to adequate predictions and conclusions. At the same time, the population of the affected area felt betrayed and angry, no longer willing to accept any more risk at all. When an earthquake of unusual severity in 2012 coincided with the suddenly voiced criticism and new risk assessment by the Dutch Regulatory Agency on Mining, followed by the highly critical report of the Dutch Safety Board, a new advocacy coalition between local residents, environmentalists, and safety experts emerged. The unprecedented public backlash incriminated the organizations involved in Dutch gas exploitation company NAM, eventually forcing a stop to natural gas extraction (Schmidt et al., 2018).

In these cases, the organizations in focus ignored signals of the impending threat and failed to see the crisis coming. Responsible actors did not regard the hazard nor the ensuing crisis as their problem alone, while public scrutiny quickly turned in their direction and incriminated them. As such, the frame used to address an emerging problem was ill fit to the actual situation, and based on a habituated response rather than on an accurate assessment of what the situation required (Weick, 1993). A crisis that started external to the organization soon 
implicated the organization, leading to public criticism of the organization's legitimacy. In these cases there still is a direct link between the hazard and the organization, but this is not necessarily the case when the crisis is about the organization.

\section{Crisis About the Organization: Causes of Institutional Crises}

Although a crisis could be any negative, profoundly disturbing surprise to an organization, some crises involve little to no physical threat or harm while simultaneously encompassing more than a one-off scandal. Here, the concept of institutional crisis offers more conceptual and analytical leverage. Institutions are, in Selznick's famous definition, organizations "infused with value beyond the technical requirements of the task at hand" (Selznick, 1957, p. 17). An institutional crisis suggests that the institution faces an unexpected drop of public and political support and a breakdown of organizational legitimacy (Alink et al., 2001). Previous research on institutional crisis instructs us that in a crisis, the organization's or policy sector's institutional integrity is at stake (Boin \& 't Hart, 2000, p. 12).

An organization enjoys institutional integrity when organizational capacity (resources, skills), stakeholder support (both internally and externally), leadership, and authority base are all lined up in service of a clear and uncontested mission (Ansell et al., 2016). These pillars of institutional integrity are interrelated in their effect on the organization; there has to be a balance. A crisis looms when an organization is gradually bereaved from its resources and authority (FEMA in the early 2000s), or no longer enjoys external stakeholder support (TVA in the 1980s), or embarks on a mission for which it does not have the capacity or over-estimates its own can-do ability (as suggested by the CAIB 2003 report on NASA and the space shuttle program, see: Starbuck \& Farjoun, 2009). An ideological imbalance can also be imposed on the organization, for instance, evidenced by President Reagan's political appointment of conservative pro-life administrators to head U.S. public health organizations (Blanchard, 1994).

Another way to identify the foundation of institutional integrity is by looking at the institutional structure of an organization in terms of software and hardware. Hardware refers to structures, procedures, governing arrangements, and policy instruments, whereas software refers to policy ideas, core values of the organization, and its governing philosophy (Alink et al., 2001; Ansell et al., 2016). Institutional integrity implies a synergy between hardware and software (internally), and public and political support (externally) for both. Boin and Goodin (2007) discern between the internal dimension of institutionalization, which they call institution building (basically, establishing or maintaining the synergy between the hardware and the software) and the external dimension, which they call domestication. Domestication with respect to hardware means that the organization takes on the signature of the policy field in which it develops and responds to "generalized perceptions of what is desirable in a public organization” (Boin \& Goodin, 2007, p. 43; cf. Powell \& DiMaggio, 1991; Oliver, 1992; Suchman, 1995). Domestication with respect to software means that the core philosophy of the organization and the values its stands for should not deviate from what its core stakeholders expect. A deviant institution is considered "recalcitrant" when it does not adhere to its own foundations of institutional integrity (Boin \& Goodin, 2007). 
Institutional erosion can cause the pillars of integrity to stumble and fall. The organization, driven by hubris or ambition, has deviated too much from what was expected in its environment. The organizational goals may have evolved into what some would call adaptation and others see as institutional drift (Salines et al., 2012). Or the environment has changed while the institution rigidly held onto established beliefs and practices. Ansell et al. (2016, p. 419) define institutional erosion as an incubation period in which stakeholders increasingly come to see the institution's performance as problematic. Institutional erosion means that a performance gap between external expectations and what the institution actually delivers increasingly becomes manifest and problematic (Ansell et al., 2016; Boin \& 't Hart, 2000).

Meanwhile, all organizations in the public sector struggle with a performance gap. After all, unlike restaurants or factories, public organizations are often created to address wicked problems for which no private market solution exists (Van Thiel \& Yesilkagit, 2014). Their missions are ambiguous and by definition "impossible" to fulfill (Goodsell, 2010; Hargrove \& Glidewell, 1990; Van Witteloostuijn et al., 2018). The performance deficit is not necessarily a problem, as Ansell et al. (2016) argue, as no one expects the police to prevent all crime or the welfare agencies to solve child poverty. Within limits, organizations can deviate, continue to operate sub-optimally but unproblematized, and still maintain their legitimacy (Hong \& Sohn, 2014).

Yet, performance or operations that go against the core values of the organization or its mission, or that indicate an inexcusable gap between reasonable expectations and actual output, can become highly problematic. An example of such a situation would be the dissolution of the Dutch interregional criminal investigation organization, when it became apparent that police had used inappropriate means such as the use of civilian moles and police-controlled drug transports as bait for organized crime (Boin \& 't Hart, 2000). In such cases, an institutional crisis arises, similar to what Ansell and Vogel (2006, p. 12) call contested governance: "a particularly intense and broad-based conflict about the fundamental assumptions and institutional frameworks through which a policy domain is governed." The criticism on the performance gap or the conflict about underlying policy assumptions are usually triggered by a negative event or unfavorable news that exposes the institutional erosion.

What follows is a rapid decline in political and public support and a media fire storm scrutinizing the criticized institution against new standards, leaving an organization overwhelmed and often paralyzed by the sudden eruption of critique. The previous recipe for success has turned into a record of rigidity; the prior yardsticks for performance no longer count; and reliable partners of the past are now considered an incriminating cartel.

Particularly highly institutionalized organizations that have become hallmarks and champions of public service are vulnerable to erosion and crisis: their hubris breeds unanticipated failure, and their spotless reputation increases the disappointment (Ansell \& Vogel, 2006).

In previous work, some policy sectors become the subject of intense public scrutiny, whereas others continuously flounder unnoticed (Ansell et al., 2017). The authors argue that the performance deficit itself cannot explain this variance. In some cases, the performance of a policy sector had in fact improved in the years leading up to an institutional crisis. Boin and Otten (1996) and Resodihardjo (2006a) show how the Dutch detention sector, for instance, became the subject of an institutional crisis in the early 1990s, when a series of dramatic 
escapes cast a spotlight on the sector. Media attention rose, political venues changed, and political executives and administrative chiefs used the window of opportunity to finally get approval for double bunking (more than one prisoner in a cell) and the creation of a "supermax": a special security unit (Resodihardjo, 2006a). Although a "focusing event" seems to have punctuated the status quo and created a window for change, the actual performance of the Dutch sector had been on the rise: when the crisis broke, the number of escapes had been lower than ever before. In fact, the number of escapes had sharply decreased in the preceding decade, "starting with 4 out of 1,000 inmates in 1984, to 2 per 1,000 in 1990, and 1 per 1,000 in 1992" (Ansell et al., 2017, p. 420, see also Boin \& Otten, 1996).

Around the same time, a series of prison riots in the United Kingdom induced an institutional crisis for the Prison Service of England and Wales. The Strangeways riots in a Manchester detention facility in 1990 led to three fatal casualties, 133 wounded inmates, and 282 wounded prison guards. The total costs of the riots exceeded $£ 100$ million. Attention for policy failure peaked in press and politics but did not seem to put sector reform on the political agenda at first instance. It would take an authoritative public inquiry report (the Woolf Committee) to fundamentally change perspective on the way U.K. prisons were organized (Resodihardjo, 2006b). The detention policy philosophy turned from a security-oriented "warehouse" approach (locking people up) to a more rehabilitation-oriented re-prioritization in the entire U.K. prison sector (p. 203).

In a third, more recent, prison sector institutional crisis, the Washington Department of Corrections inadvertently released large numbers of inmates before their sentences expired. Some of the released inmates committed serious crimes while illegitimately out of prison. And yet, it was not failure of early release itself, but the combined duration and scope of the failure and all the missed opportunities to detect and adequately respond to the situation, that escalated the political crisis that followed (Useem et al., 2017).

The cases suggest that not so much the actual performance gap matters for the scope of the institutional crisis, but the perception or recognition (or absence of recognition such as in the Washington case) thereof, and the subsequent policy reorientation it instigates (whether an external committee redefines the policy problem, such as in the U.K. case; or internal actors seize the opportunity window, such as in the Dutch case). Although there has been substantial attention for how these turbulent episodes affect the agenda-setting process and potential policy change, attention for how organizations themselves cope with the crisis that affects not only their operations but also their legitimacy and reputation is less prevalent and seems to be scattered across different disciplines.

\section{Organizational Crisis Management}

Once a crisis hits, it is the task of crisis managers to reduce its effects and try to contain the situation. In the case of organizational crisis management (of any type), crisis managers need to deal with the causes and consequences of crisis itself, but equally important, they often also need to cope with a sudden loss in legitimacy because their own organization is under scrutiny (Boin \& 't Hart, 2000). Such crises may stretch across prolonged periods of time and trigger intense media attention that gives rise to public scrutiny of existing institutional arrangements, point at specific errors that become examples of chronic failure, and challenge 
authority and legitimacy of the sector as a whole (Ansell et al., 2016). This means that crisis managers need to combine crisis management with stakeholder engagement in an attempt to restore trust and legitimacy and embark in a period of relationship management (Coombs \& Holladay, 2015).

Organizational crisis management requires both "functional" management and "political" management (Nohrstedt et al., 2018). Functional crisis management concerns processes that are directly focused at containing the crisis, such as information sharing, coordination, sensemaking, and decision making (Noori et al., 2016; Schakel \& Wolbers, 2019; Treurniet \& Wolbers, 2020; Wolbers \& Boersma, 2019; Wolbers et al., 2018). The political dimension of crisis management pertains to processes that aim to alleviate the effects of the crisis by means of meaning-making, rendering accountability, and external communication (Boin, 't Hart, et al., 2017). Functional and political dimensions of crisis management are generally believed to take place in different phases of the crisis, though both can have a significant effect on each other (Boin, Kuipers, et al., 2017). Still, also during the functional processes different interest and stakes can materialize that give rise to the bureau politics of crisis management (Rosenthal et al., 1989). In order to better understand the functional and political dimension of crisis management in different types of organizational crises, their relation is discussed in the following paragraphs by making use of the previous discussed examples from several well-known crises.

\section{Management of Crises in Organizations}

When any organizational crisis materializes, there is often a direct relation between functional and political crisis management. Functional responses to cope with the crisis, for example, make sense of the situation and coordinate a response, have an effect on the public perception of crisis management, thus making it political. This interplay is clearly visible in the previously discussed example of the chemical disaster in Bhopal. When the magnitude of the chemical spill became visible, the situation turned into an organizational crisis for the corporation Union Carbide. Immediately questions arose to what extent the company had put safety precautions in place to prevent spills or contain its effects. As such, the failure of foresight in the Union Carbide plant denoted the starting point of political crisis management. Stories of bad maintenance and cost reductions fueled the image of a company that did not take safety precautions seriously. In an attempt to repair initial reputation damage, Union Carbide engaged in a process of meaning-making to launch a counter-frame. The company publicly contested the accident frame by arguing that a disgruntled worker had intentionally forced water into the tank, thus launching a sabotage frame (Chouhan, 2005). This counter-framing marked the start of a prolonged period of deflecting accountability, which would eventually result in delaying the compensation of the victims for over 16 years, and left the plant site severely contaminated (De Jonge, 2011).

Launching a counter-frame highlights meaning-making as an important dimension of political crisis management. Meaning-making refers to the attempt to change the narrative of the crisis by presenting a convincing story or alternative frame through which events should be viewed or interpreted (Boin, 't Hart, et al., 2017). Failure to impose a dominant frame means that opponents gain momentum in imposing their frames of the situation, which is likely to be a less supportive version of the ongoing crisis management efforts. Meaning-making thus is 
crucial to the long-term legitimacy of public institutions (Rosenthal et al., 2001). Union Carbide's sabotage frame, intended to cast doubt on its responsibility, backfired as bad maintenance and poor factory oversight were seen as the main causes of the crisis (Weick, 1988, 2010).

Twenty years after the disaster, when Dow Chemicals had taken over Union Carbide and inherited the disaster's legacy and responsibility, the reputation crisis suddenly revived when a former Greenpeace activist who became known as "the Yes-man," claiming to be an official company spokesman issued a press statement on BBC to state that Dow Chemicals claimed full responsibility for the Bhopal catastrophe. The BBC interviewed the con man in their primetime news, where he promised-on behalf of Dow-a $\$ 12$ billion compensation for the victims and a full remediation of the plant site. In response, Dow Chemicals issued a press statement denying involvement, which backfired and spurred even greater coverage. The consequence was that the Dow's stock market shares fell over $4 \%$ in about 20 minutes, liquidating around $\$ 2$ billion off its market value. Still, afterward market shares rebounded, and Dow Chemicals was able to deflect this sudden peak of attention.

An organizational crisis can clearly create a window of opportunity for advocacy and interest groups to claim policy alternatives (Nohrstedt, 2013). However, organizations under public scrutiny are likely to engage in a well-known strategy, known as "kicking the ball into the long grass" (Sulitzeanu-Kenan, 2007). When utilizing this strategy, organizations attempt to deflect attention by not acting, or postponing the response, in the hope that attention will eventually fade out.

A tactic that is often used is setting up an inquiry committee to reduce the level of public interest in the affair (Sulitzeanu-Kenan, 2007). Inquiries can, at least temporarily, remove the issue from the political arena, effectively depoliticizing it and fending off controversy (Woodhouse, 1995). Indeed, Sulitzeanu-Kenan (2007) shows that as time progresses media salience decreases, yet the same goes for events that are not investigated by an inquiry committee. In fact, the final verdict of the inquiry committee may cause new problems and will stir up negative attention again.

Jong (2019) illustrates that it is difficult for companies and governments to deal with accountability allegations when under investigation. An effective option for organizations under scrutiny is to engage in a strategy of "acknowledge and await" by acknowledging that something went wrong, while communicating that the organization will deal with the accountability question after the official investigation have given a verdict. This reflects elements of the "kicking the ball into the long grass" strategy but also gives a more concrete path in which it might be possible to share or deflect accountability with other organizations in the long term, as it often turns out that multiple organizations play a role in causing a crisis (Jong, 2019).

\section{Management of Crises to Organizations}

In the case of a crisis to an organization, a crisis can turn political even when there is little functional crisis management in progress. A good example is the previously discussed case of human-induced earthquakes in Groningen, during which, in an ongoing struggle for agenda setting and political attention, advocacy groups finally were able to influence the government 
to stop the gas production (Schmidt et al., 2018). Although the damage to the houses was real, there was little functional crisis management in place as the earthquakes themselves remained relatively weak. Instead, the national government and the gas production company resorted to managing the political crisis at first by pursuing various conservative management strategies aimed at restoring legitimacy. This shifted the focus from the actual increase in safety risk posed by the earthquakes toward the perceived increase in feelings of insecurity of local inhabitants. To counteract the frame promoted by the gas production company, the provincial government of Groningen formed a research committee. The committee identified negative impacts on the housing market, cultural heritage sites, and quality-of-life of residents. Its findings were widely reported in the national media, setting the agenda for the political discussion on the negative effects of the earthquakes on the region.

In response to the societal unrest, the government instigated several governance arrangements to set up a dialogue with affected communities and interest groups. As the NAM and government retained their exclusive influence over the gas production policy, the actual influence of the local actors and interest groups remained limited. These talks can be seen as an attempt of political crisis management to engage in collective meaning-making and framing of the situation together with the affected community. As the interest groups and affected communities lacked actual influence on the gas production policy, the governance arrangement had little success. In response, the affected community and interest groups ramped up their efforts to put earthquakes back on the political agenda.

The political crisis management process continued, and to come up with a satisfactory solution, the government launched a new governance arrangement in the form of a National Coordinator Groningen (NCG). The NCG still lacked formal decision making on actual gas production policies, but would be able to influence the decision making through the allocation of budgets for reconstructing damaged houses. The efforts of the NCG provided some relief for the citizens in the province of Groningen but still did little to improve their situation as ambiguity about the extent and level of compensation remained. Thus, the crisis persisted and continued to remain a problematic policy dossier for the national government.

Interestingly, in this crisis to the organization, political crisis management is predominantly visible through the creation of several collaborative governance arrangements (Schmidt et al., 2018). As the scope of the earthquakes remained limited, the crisis never took the shape of a sudden-onset crisis that would require a swift functional management response. Instead, the crisis can be considered as a creeping crisis, which offers "a threat to widely shared societal values or life-sustaining systems that evolves over time and space, is foreshadowed by precursor events, subject to varying degrees of political and/or societal attention, and impartially or insufficiently addressed by authorities" (Boin et al., 2020, p. 7).

Managing a creeping crisis is difficult as, because of their ambiguous character, the "ownership" of the crisis tends to be ill-defined, and political motives can play an important role in the decision-making process (Boin et al., 2020). Deriving sufficient attention for the crisis is thus the first political crisis management challenge. It features attempts to put the crisis on the agenda through lobbying by interest groups, while the NAM and the Ministry of Economic Affairs attempted to reduce feelings of uncertainty by giving room to local interest 
parties to voice their concern. The latter strategy had little effect and even worked counterproductive as the local action and interest groups successfully communicated their message that they were not taken seriously.

In the course of the protracted crisis, the real political power remained with the Ministry of Economic Affairs and the NAM. Both actors were very eager to minimize the potential dangers of increasing earthquakes and were quick to ensure both a speedy disappearance of earthquakes from the political agenda and a decrease in the likelihood of political intervention (Boin \& 't Hart, 2000). This strategy corresponds with extensive literature on blame avoidance following crisis situations (e.g., Baekkeskov \& Rubin, 2017; Hood, 2011; Resodihardjo et al., 2016). In the end, this strategy eventually backfired as more and more political will arose to help out and compensate the people in Groningen. This cumulated after the new elections, where the new national government decided to reduce gas production in the coming years and completely stop gas production in Groningen in 2030. Especially in this final phase of the human-induced earthquake crisis in Groningen, a change from crisis to an organization toward a crisis about the organization is visible when more and more actors started questioning the underlying policy philosophy of the gas production.

\section{Management of Crisis About the Organization}

A crisis about the organization is likely to take the form of an institutional crisis. An institutional crisis could be the consequence of the failure to prevent a disaster from happening or escalating (such as in the Bhopal case), or of the failure to respond to threats for which responsibility is attributed to the organization (such as the earthquakes in Groningen to the gas production company, or Ebola to the WHO). There is a difference, though, between an organizational crisis, which leads to intense criticism and reputation damage as a result of the situation at hand, and an institutional crisis. In the case of institutional crisis, the entire underlying governance framework or policy philosophy becomes contested.

Although the functional tasks of crisis management are key to get the initial response underway, problems experienced during this initial crisis management can quickly trigger the politics of crisis management. Actors engage in different attempts to deflect attention, mitigate the damage, and change the dominant narratives around the crisis. Still, once an institutional crisis has begun, there often is no turning back. In that case, assuming accountability and introducing reforms to prevent the disaster from happening again are seen as viable approaches to alleviate the crisis.

Boin and 't Hart (2000) distinguish reformist strategies that aim to bring institutional features of a public policy or agency back in balance (for instance, its purpose and resources, or its authority and its audience) to create a new fit between an organization and its changed environment. Conservative strategies, by contrast, aim to "maintain the institutional essence in the face of change" (Boin \& 't Hart, 2000, p. 21). Reformist strategies are radical efforts to try to restore the legitimacy of a policy subsystem by introducing reforms that affect the core values and ways of working of the organization. Conservative strategies aim to restore legitimacy through incremental changes to the policy subsystem without resorting to overtly drastic changes to its institutional arrangements. Rather than co-opting opposing views, in 
such a scenario, policy actors may choose to evaluate and improve on existing policies and venues. Legitimacy is then restored by projecting stability and gradually improving blameworthy failures (Ansell et al., 2016).

In the prison sectors previously discussed, large-scale institutional reforms prevailed in the Netherlands and the United Kingdom, whereas more instrumental measures aimed at early detection of issues were taken in the Washington case. In the Netherlands, the actual extent of the policy failures was limited, but the public perception-contrary to measurable performance-allowed for drastic interventions in terms of previously unthinkable reforms. Clever policy brokering by political and administrative executives resulted in the introduction of an extreme secure detention facility (the "supermax") in Vught, and double bunking in other Dutch prison facilities (Boin \& Otten, 1996). The authoritative policy reframing of the Woolf Committee after the Strangeways riots in the United Kingdom gave way to address persisting detention policy problems such as trebling (three inmates per cell), and replaced the policy orientation from punishment and security toward rehabilitation in the entire U.K. prison sector (Resodihardjo, 2006a). In Washington, the Department of Corrections realized that its biggest failure had been to take appropriate action on early warnings, and sought to increase organizational vigilance among its administrative staff to detect imminent issues and emergencies, and thereby create a culture of awareness in the organization (Useem et al., 2017, p. 387).

The internal policy brokering in the Dutch case and the external impetus needed for profound reform in the British case suggest different degrees of leadership and institutionalization. Ansell et al. (2017) suggest that reform outcomes depend on the combination of the degree of institutionalization and the force of agency, defined as the leadership ability to recognize threats in its environment and pre-emptively sacrifice or change elements of the organization in order to preserve core values. In this line of reasoning, even a highly institutionalized sector or organization, with a strong mission, high legitimacy, and long-established ways of working, can face an institutional crisis. When inertia is high and agency low, external actors can drive the reform agenda just like the Woolf Committee did in the United Kingdom (Resodihardjo, 2006a). When agency is high and so is inertia in the organization or sector, its administrative leaders can seize the opportunity of the crisis for agenda renewal, as they did in the Dutch prison case. The more incremental strategy in the Washington case would be indicative of dynamic conservatism.

When no reforms to the core policy philosophy or institutionalized governance arrangements occur, the question arises whether a situation qualifies as an institutional crisis. It often seems in the literature that real institutional crises cannot go without institutional reform, because one of the characteristics of this type of crisis is the fundamental criticism on the core values and operations of the organization or policy sector (Boin \& 't Hart, 2000). The entire reform debate and its implementation are part of the crisis experience of the organizations at hand (Kuipers, 2006).

When institutions do not "storm the agenda" (Ansell et al., 2017), the crisis may fall in the category of "crisis to the organization" discussed previously. The Washington case shows that the organization is severely criticized and its legitimacy tumbles, because of a performance gap that pertains directly to the core values it stands for (making society safer by ensuring that convicted criminals serve their sentence). The values itself are not subject to discussion, nor is the way the organization addresses these values by detaining them. It is the failure to 
deliver that brings the crisis to the organization. In the U.K. and Dutch cases, the policy philosophy (security vs. rehabilitation) or the key instruments (types of detention facilities, detention regime) are subject to debate-and ultimately institutional reform that deepens the crisis for the organization involved.

\section{Conclusion and the Road Ahead}

This article offers a typology for organizational and institutional crisis management that portrays three sorts of crises: a crisis in an organization, a crisis to the organization and a crisis about the organization. A summary table of characteristics is provided in the appendix. A crisis in an organization occurs when an immediate threat or incident, confined to the organization itself, completely upsets organizational performance. These crises, often identified by the organization's name (e.g., BP oil spill), involve a combination of functional and political crisis management. Functional crisis management processes are aimed at containing the direct effects of the crisis, whereas political crisis management encompass dealing with managing the reputational effects and/or accountability. The discussion of the chemical plant disaster in Bhopal illustrated how the response was initially characterized by functional crisis management, and (even years later) the crisis required extensive political interventions to cope with accountability claims. 


\begin{tabular}{|c|c|c|}
\hline Type & Definition & Causes of Crisis \\
\hline $\begin{array}{l}\text { Crises in } \\
\text { organizations }\end{array}$ & $\begin{array}{l}\text { A tangible, immediate } \\
\text { threat or incident that } \\
\text { completely upset an } \\
\text { organization's primary } \\
\text { process or performance } \\
\text { while both cause and } \\
\text { problems are confined to } \\
\text { the organization and } \\
\text { those affected by its } \\
\text { malperformance }\end{array}$ & $\begin{array}{l}\text { A combination of } \\
\text { individual and } \\
\text { collective human } \\
\text { errors during the } \\
\text { risk-management } \\
\text { process that is } \\
\text { characterized by } \\
\text { complexity and } \\
\text { unruly technology } \\
\text { within organizations }\end{array}$ \\
\hline
\end{tabular}

Crisis Management

A balanced interplay

between functional

and political crisis

management.

Functional responses

to cope with the crisis

have a direct effect on

the public perception

of crisis management,

which can quickly call

for a political

response.

Crisis to the

organization
A threat or damage

occurring outside the

organization at hand but

implicating the

organization by

attribution of

responsibility or

culpability
A failure to see a crisis coming
because of blind spots and rigid beliefs about the task environment that prevent organizations from taking adequate precautions

"Ownership" of the crisis tends to be ambiguous and illdefined, giving a key role to powerplay motives. Framing and deriving support for the crisis response is thus first and foremost a political crisis management challenge.

An institutional crisis requires extensive political and organizational leadership for reformist strategies to re-create a new fit between the organization and its altered environment. Without a reform agenda, the crisis is managed as a crisis to the organization, focusing only on the reputation damage. 
Page 19 of 27

Printed from Oxford Research Encyclopedias, Politics. Under the terms of the licence agreement, an individual user may print out a single article for personal use (for details see Privacy Policy and Legal Notice).

Subscriber: OUP-Reference Gratis Access; date: 25 March 2021 
A "crisis to the organization" occurs when an outside threat or incident implicates the organization by attribution of responsibility or culpability. Often there is limited necessity for functional crisis management, as the organizations' core processes are not directly disturbed, but this sort of crisis does require extensive political crisis management. The case of the Ebola outbreak and the human-induced earthquakes Groningen earthquakes showed that a crisis can affect the organization even without much functional crisis management in place. Indeed, affected organizations did not recognize a crisis in the making, and it came to back to haunt them as culprits for failing to prevent it or stop escalation. It showed the predominant political nature of this crisis type whereby the role of rigid beliefs and blind spots kept organizations from recognizing the importance of the ongoing crisis. Instead, it required them to invest extensively in political crisis management processes, to engage in stakeholder management, meaning-making, and rendering accountability.

A "crisis about the organization" occurs when the organization's perceived performance deficit threatens its legitimacy letting the organization become subject to intense scrutiny and criticism. The result is an institutional crisis, with a relatively strong decline and unusually low levels of legitimacy. Such a crisis is looming when an organization is gradually deprived of its resources and authority, no longer enjoys external stakeholder support, embarks on a mission for which it does not have the capacity, or overestimates its own abilities. A gradual process of institutional erosion exposes the performance gap between external expectations and what the institution actually delivers. It is not so much the actual performance gap that matters for the scope of the institutional crisis, but the perception or recognition and the subsequent policy reorientation it instigates. In any case, when an organization is confronted with a crisis about itself, it involves extensive political crisis management in the shape of reforms to foster a new policy orientation. Without a clear reform agenda, the crisis falls in the category of a crisis to the organization, where the crisis (only) pertains to intense criticism and reputation damage as a result of the situation at hand. In the case of institutional crisis, the entire underlying governance framework or policy philosophy is contested.

Given examples show that these three typologies are not static descriptions that encompass an entire crisis period, but often turn out to be different stages in a crisis, highlighting the cross-over effects between functional and political crisis management. A crisis in an organization can become a crisis about the organization, when, as consequence of the crisis, the functioning of the organization is scrutinized. A crisis to the organization may evolve into a crisis about the organization, that is, an institutional crisis, when not only the organization but the entire governance framework becomes contested. Overall, an organizational crisis of any type requires a swift but balanced response on multiple levels. It starts with developing an adequate perception of the crisis, moves toward identifying the cause and its disruptive consequences, and eventually results in managing the accountability process and the organization's reputation.

This discussion of the different crisis types highlights several topics for future research. First, each crisis type offers a unique interplay between functional and political crisis management. This highlights several questions in cross-over effects. When and why do organizations take the step to move from functional toward political crisis management, and can a failure to engage in meaningful political crisis management trigger a new functional crisis? Second, the question arose whether the crisis's induced speed reflects a different dynamic between 
typologies and their functional or political management. Does a sudden-onset crisis involve a different response from a creeping crisis? Finally, more insight is needed into how an organizational crisis moves from one typology to another, to understand the prolonged period of crisis management.

In conclusion, this crisis typology might help scholars to discern more clearly between functional and political approaches to crisis management. A systematic overview on what approaches are used for what crisis type and in what way lays down the foundations of the argument here. It showed that there is no single best response to organizational crises: appropriate responses are commensurate to the crisis type at hand and to different phases of a crisis. Still, discerning between crisis typologies opens a research agenda to provide a better understanding of the relation between internal and external dynamic of a crisis. This typology might inspire scholars to ask new questions about the nature and consequences of organizational crises.

\section{References}

Alink, F., Boin, A., \& 't Hart, P. (2001). Institutional crises and reforms in policy sectors: The case of asylum policy in Europe. Journal of European Public Policy, 8(2), 286-306.

Ansell, C., \& Boin, A. (2019). Taming deep uncertainty: The potential of pragmatist principles for understanding and improving strategic crisis management. Administration \& Society, 51(7), 1079-1112.

Ansell, C., Boin, A., \& Kuipers, S. (2016). Institutional crisis and the policy agenda. In N. Zahariadis (Ed.), Handbook of public policy agenda setting (pp. 415-432). Edward Elgar.

Ansell, C., Trondal, J., \& Øgård, M. (2017). Governance in turbulent times. Oxford University Press.

Ansell, C., \& Vogel, D. (2006). What's the beef? The contested governance of European food safety. MIT Press.

Baekkeskov, E., \& Rubin, O. (2017). Information dilemmas and blame-avoidance strategies: From secrecy to lightning rods in Chinese health crises. Governance, 30(3), 425-443.

Baize, S., Pannetier, D., Oestereich, L., Rieger, T., Koivogui, L., Magassouba, N. F., Sorropogui, B., Sow, M. S., Keita, S., De Clerck, H., Tiffany, A., Dominguez, G., Loua, M., Traoré, A., Kolié, M., Malano, E. R., Heleze, E., Bocquin, A., Mély, S., Raoul, H., . . Günther, S. (2014). Emergence of Zaire Ebola virus disease in Guinea. New England Journal of Medicine, 371(15), 1418-1425.

Blanchard, D. (1994). The anti-abortion movement and the rise of the religious right: From polite to fiery protest. Twayne.

Boin, A., Ekengren, M., \& Rhinard, M. (2020). Hiding in plain sight: Conceptualizing the creeping crisis. Risk, Hazards \& Crisis in Public Policy, 11(2), 116-138.

Boin, A., \& Goodin, R. E. (2007). Institutionalizing upstarts: The demons of domestication and the benefits of recalcitrance. Acta Politica, 42(1), 40-57. 
Boin, A., \& 't Hart, P. (2000). Institutional crises and reforms in policy sectors. In H. Wagenaar (Ed.), Government institutions: Effects, changes and normative foundations (pp. 9-31). Springer, Dordrecht.

Boin, A., \& 't Hart, P. (2003). Public leadership in times of crisis: Mission impossible? Public Administration Review, 63(5), 544-553.

Boin, A., 't Hart, P., Stern, E., \& Sundelius, B. (2017). The politics of crisis management: Public leadership under pressure (2nd ed.). Cambridge University Press.

Boin, A., Kuipers, S. L., \& 't Hart, P. (2017). The crisis approach. In H. Rodríguez, W. Donner, \& J. Trainor (Eds.), Handbook of disaster research (pp. 23-38). Springer.

Boin, R. A., \& Otten, M. H. (1996). Beyond the crisis window for reform: Some ramifications for implementation. Journal of Contingencies and Crisis Management, 4(3), 149-161.

Bigley, G. A., \& Roberts, K. H. (2001). The incident command system: High reliability organizing for complex and volatile task environments. Academy of Management Journal, 44, 1281-1299.

Bundy, J., Pfarrer, M. D., Short, C. E., \& Coombs, W. T. (2017). Crises and crisis management: Integration, interpretation, and research development. Journal of Management, 43(6), 16611692.

Chouhan, T. R. (2005). The unfolding of Bhopal disaster. Journal of Loss Prevention in the Process Industries, 18(4-6), 205-208.

Comfort, L. K. (2007). Crisis management in hindsight: Cognition, communication, coordination, and control. Public Administration Review, 67, 189-197.

Coombs, W. T., \& Holladay, S. J. (2002). Helping crisis managers protect reputational assets: Initial tests of the situational crisis communication theory. Management Communication Quarterly, 16(2), 165-186.

Coombs, W. T., \& Holladay, S. J. (2015). Public relations' "relationship identity" in research: Enlightenment or illusion. Public Relations Review, 41(5), 689-695.

Coltart, C. E., Lindsey, B., Ghinai, I., Johnson, A. M., \& Heymann, D. L. (2017). The Ebola outbreak, 2013-2016: Old lessons for new epidemics. Philosophical Transactions of the Royal Society B: Biological Sciences, 372(1721), 1-24.

Cornelissen, J. P., Mantere, S., \& Vaara, E. (2014). The contraction of meaning: The combined effect of communication, emotions, and materiality on sensemaking in the Stockwell shooting. Journal of Management Studies, 51(5), 699-736.

De Jonge, A. (2011). Transnational corporations and international law. Accountability in the Global Business Environment. Edward Elgar.

Gephart, R.P., Jr., Van Maanen, J., \& Oberlechner, T. (2009). Organizations and risk in late modernity. Organization Studies, 30(2-3), 141-155.

Goodsell, C. T. (2010). Mission mystique: Belief systems in public agencies. SAGE. 
Hargrove, E. C. (1994). Prisoners of myth: The leadership of the Tennessee Valley Authority, 1933-1990 (Vol. 39). Princeton University Press.

Hargrove, E. C., \& Glidewell, J. C. (1990). Impossible jobs in public management. University Press of Kansas.

Hermann, C. F. (1963). Some consequences of crisis which limit the viability of organizations. Administrative Science Quarterly, 61-82.

Hong, S., \& Sohn, H. (2014). Informal institutional friction and punctuations: Evidence from multicultural policy in Korea. Public Administration, 92(4), 1075-1089.

Honigsbaum, M. (2017). Between securitisation and neglect: Managing Ebola at the borders of global health. Medical History, 61(2), 270-294.

Hood, C. (2011). The blame game: Spin, bureaucracy, and self-preservation in government. Princeton University Press.

James, E. H., Wooten, L. P., \& Dushek, K. (2011). Crisis management: Informing a new leadership research agenda. Academy of Management Annals, 5(1), 455-493.

Jong, W. (2019). Blaming others during an incident inquiry. An analysis of "blame games" in the aftermath of crises. Tijdschrift voor de Communicatiewetenschap, 47(2), 116.

Kahn, W. A., Barton, M. A., \& Fellows, S. (2013). Organizational crises and the disturbance of relational systems. Academy of Management Review, 38(3), 377-396.

Kalbassi, C., \& Kauf, P. (2017). Identifying crisis characteristics: Cross-case relevant crisis character variables for public administrations. Risk, Hazards \& Crisis in Public Policy, 8(1), 6890 .

Kamradt-Scott, A. (2016). WHO's to blame? The World Health Organization and the 2014 Ebola outbreak in West Africa. Third World Quarterly, 37(3), 401-418.

Kekulé, A. S. (2015). Learning from Ebola virus: How to prevent future epidemics. Viruses,7(7), 3789-3797.

Kenis, P., Schol, L. G., Kraaij-Dirkzwager, M. M., \& Timen, A. (2019). Appropriate governance responses to infectious disease threats: Developing working hypotheses. Risk, Hazards \& Crisis in Public Policy, 10(3), 275-293.

Kettl, D. F. (2003). Contingent coordination: Practical and theoretical puzzles for homeland security. American Review of Public Administration, 33(3), 253-277.

Kuipers, S. L. (2006). The crisis imperative: Crisis rhetoric and the reform of social security in Belgium and the Netherlands. Amsterdam University Press.

Kuipers, S. L., \& Boin, A. (2010). Path dependence, institutionalization and the decline of two public institutions. In G. Schreyögg \& J. Sydow (Eds.), The hidden dynamics of path dependence (pp. 50-68). Palgrave Macmillan, London.

Kuipers, S. L. (2019). The contingency perspective to crisis management. Risk, Hazards \& Crisis in Public Policy, 10(3), 266-274. 
Lagadec, P. (1993). Preventing chaos in a crisis. McGraw-Hill.

Lakoff, A. (2015). Two states of emergency: Ebola 2014_https://limn.It/articles/two-states-ofemergency-ebola-2014/>. Limn 5: Ebola's Ecologies.

La Porte, T. R. (1996). High reliability organizations: Unlikely, demanding and at risk. Journal of Contingencies and Crisis Management, 4(2), 60-71.

Laufer, D., \& Wang, Y. (2018). Guilty by association: The risk of crisis contagion, Business Horizons, 61(2), 173-179.

Leijtens, V. (2019). The underlying dynamics of the institutional crisis of the Dutch Tax and Customs Administration: An unsupervised machine learning approach (No. 1152). EasyChair.

Maitlis, S., \& Sonenshein, S. (2010). Sensemaking in crisis and change: Inspiration and insights from Weick (1988). Journal of Management Studies, 47(3), 551-580.

McInnes, C. (2015). WHO's next? Changing authority in global health governance after Ebola. International Affairs, 91(6), 1299-1316.

Nohrstedt, D. (2013). Advocacy coalitions in crisis resolution: Understanding policy dispute in the European volcanic ash cloud crisis. Public Administration, 91(4), 964-979.

Nohrstedt, D., Bynander, F., Parker, C., \& 't Hart, P. (2018). Managing crises collaboratively: Prospects and problems-a systematic literature review. Perspectives on Public Management and Governance, 1(4), 257-271.

Noori, N. S., Wolbers, J., Boersma, K., \& Vilasís-Cardona, X. (2016, May). A dynamic perspective of emerging coordination clusters in crisis response networks. In A. H. Tapia, P. Antunes, V. A. Bañuls, K. Moore, \& J. Porto de Albuquerque (Eds.), Proceedings of the ISCRAM 2016 Conference, Rio de Janeiro, Brazil.

Oliver, C. (1992). The antecedents of deinstitutionalization. Organization Studies, 13(4), 563588.

Pauchant, T. C., \& Mitroff, I. I. (1992). Transforming the crisis-prone organization: Preventing individual, organizational, and environmental tragedies. Jossey-Bass.

Pearson, C. M., \& Clair, J. A. (1998). Reframing crisis management. Academy of Management Review, 23(1), 59-76.

Perrow, C. (1984). Normal accidents. Living with high risk technologies. Basic Books.

Powell, W. W., \& DiMaggio, P. J. (1991). The new institutionalism in organizational analysis. University of Chicago Press.

Reason, J. (2000). Human error: Models and management. British Medical Journal,320(7237), 768-770.

Resodihardjo, S. L. (2006a). Crisis and change: Understanding crisis-reform processes in Dutch and British prison services. Optima Grafische Communicatie. 
Resodihardjo, S. L. (2006b). Wielding a double-edged sword: The use of inquiries at times of crisis. Journal of Contingencies and Crisis Management, 14(4), 199-206.

Resodihardjo, S. L., Carroll, B. J., Van Eijk, C. J., \& Maris, S. (2016). Why traditional responses to blame games fail: The importance of context, rituals, and sub-blame games in the face of raves gone wrong. Public Administration, 94(2), 350-363.

Roe, E., \& Schulman, P. R. (2008). High reliability management: Operating on the edge (Vol. 19). Stanford University Press.

Roberts, K. H. (1990). Some characteristics of one type of high reliability organization. Organization Science, 1(2), 160-176.

Roe, E., \& Schulman, P. R. (2008). High reliability management: Operating on the edge (Vol. 19). Stanford University Press.

Rosenthal, U., 't Hart, P., \& Charles, M. T. (1989). The world of crises and crisis management. In U. Rosenthal, M. T. Charles, \& P. 't Hart (Eds.), Coping with crises: The management of disasters, riots and terrorism (pp. 3-33). Charles C. Thomas.

Rosenthal, U., 't Hart, P., \& Kouzmin, A. (1991). The Bureau-politics of Crisis Management, Public Administration, Vol.69(2), p.211-233.

Rosenthal, U., Boin, R. A., \& Comfort, L. K. (Eds.). (2001). The changing world of crises and crisis management. Managing crises: Threats, dilemmas, opportunities (pp. 5-27). Charles C. Thomas.

Salines, M., Glöckler, G., \& Truchlewski, Z. (2012). Existential crisis, incremental response: The eurozone's dual institutional evolution 2007-2011. Journal of European Public Policy, 19(5), 665681.

Schakel, J. K., \& Wolbers, J. (2019). To the edge and beyond: How fast-response organizations adapt in rapidly changing crisis situations <https://doi.org/10.1177/0018726719893450>. Human Relations, 0018726719893450.

Schmidt, A., Boersma, K., \& Groenewegen, P. (2018). Management strategies in response to an institutional crisis: The case of earthquakes in the Netherlands. Public Administration, 96(3), 513-527.

Selznick, P. (1957). Leadership in administration. Harper \& Row.

Starbuck, W. H., \& Milliken, F. J. (1988). Challenger: Fine-tuning the odds until something breaks. Journal of Management Studies, 25(4), 319-340.

Starbuck, W., \& Farjoun, M. (2009). Organization at the limit: Lessons from the Columbia disaster. John Wiley \& Sons.

Stern, E., \& Sundelius, B. (2002). Crisis management Europe: An integrated regional research and training program. International Studies Perspectives, 3(1), 71-88.

Suchman, M. C. (1995). Managing legitimacy: Strategic and institutional approaches. Academy of Management Review, 20(3), 571-610. 
Sulitzeanu-Kenan, R. (2007). Scything the grass: Agenda-setting consequences of appointing public inquiries in the UK: A longitudinal analysis. Policy \& Politics, 35(4), 629-650.

Treurniet, W., \& Wolbers, J. (2020, September 8). Codifying a crisis: Progressing from information sharing to distributed decision-making < https://doi.org/ 10.1111/1468-5973.12323>. Journal of Contingencies and Crisis Management.

Turner, B. A. (1976). The organizational and interorganizational development of disasters. Administrative science quarterly, 378-397.

Turner, B. A. (1978). Man-made disasters. Wykeham Science Press.

Useem, B., Pacholke, D., \& Mullins, S. F. (2017). Case study-the making of an institutional crisis: The mass release of inmates by a correctional agency. Journal of Contingencies and Crisis Management, 25(4), 382-388.

Quarantelli, E. L., \& Dynes, R. R. (1977). Response to social crisis and disaster. Annual Review of Sociology, 3(1), 23-49.

Van Thiel, S., \& Yesilkagit, K. (2014). Does task matter? The effect of task on the establishment, autonomy and control of semi-autonomous agencies. International Review of Administrative Sciences, 80(2), 318-340.

Van Witteloostuijn, A., Boin, A., Kofman, C., Kuilman, J., \& Kuipers, S. (2018). Explaining the survival of public organizations: Applying density dependence theory to a population of US federal agencies. Public Administration, 96(4), 633-650.

Weick, K. E. (1988). Enacted sensemaking in crisis situations. Journal of Management Studies, 25(4), 305-317.

Weick, K. E. (1993). The collapse of sensemaking in organizations: The Mann Gulch disaster. Administrative Science Quarterly, 38(4), 628-652.

Weick, K. E. (1995). Sensemaking in organizations (Vol. 3). SAGE.

Weick, K. E. (2010). Reflections on enacted sensemaking in the Bhopal disaster. Journal of Management Studies, 47(3), 537-550.

Weick, K. E., \& Sutcliffe, K. M. (2001). Managing the unexpected (Vol. 9). Jossey-Bass.

Wolbers, J., \& Boersma, K. (2019). Key challenges in crisis management. In R. P. Gephart Jr., C. C. Miller, \& K. S. Helgesson (Eds.), The Routledge companion to risk, crisis and emergency management (pp. 17-34). Taylor \& Francis.

Wolbers, J., Boersma, K., \& Groenewegen, P. (2018). Introducing a fragmentation perspective on coordination in crisis management. Organization Studies, 39(11), 1521-1546.

Woodhouse, D. (1995). Matrix Churchill: A case study in judicial inquiries. Parliamentary Affairs, $48(1), 24-40$.

Zegart, A. B. (2009). Spying blind: The CIA, the FBI, and the origins of 9/11. Princeton University Press. 


\section{Related Articles}

Social Complexity, Crisis, and Management

Evaluating Success and Failure in Crisis Management

Networks and Crisis Management

Frontline Workers in Crisis Management

Page 27 of 27

Printed from Oxford Research Encyclopedias, Politics. Under the terms of the licence agreement, an individual user may print out a single article for personal use (for details see Privacy Policy and Legal Notice).

Subscriber: OUP-Reference Gratis Access; date: 25 March 2021 